\title{
Introduction to the special issue
}

\section{Rachel Brooks and Paul Hodkinson, University of Surrey}

\section{Young people and participation}

Over recent years, politicians and social commentators in many countries of the world have become concerned with what is perceived to be young people's declining engagement within the political sphere. There is certainly strong evidence that turnout in national elections has fallen markedly among the youngest age groups. In the UK, for example, between 1997 and 2001 the percentage of 18-24 year olds who voted fell by 29 per cent to 39 per cent, a much greater drop than was witnessed among other age groups (Phelps 2005; Wattenberg 2003). Moreover, in 2005, when turnout in general rose slightly, it continued to decline for the 18-24 age group and remained the same for 25-34 year olds (Phelps 2005). Similar trends have been observed in other countries. Indeed, a previous special issue of the Journal of Youth Studies, on Youth and Politics (volume 6, number 3, 2003) has shown how concern about youth disengagement is driving public debate in countries as far apart as Canada, Germany and Australia.

The reasons for these patterns have been widely debated amongst policy makers and also within the academic literature. Indeed, Kimberlee (2002) usefully distinguishes between four competing explanations. Firstly, he outlines the 'youth-focussed' approach, in which disengagement from formal politics is held to be largely a result of young people's age and/or their social background. Here, responsibility for non-participation is located at the individual level, and young people are often compared unfavourably with their counterparts who grew up in the 1960s. This perspective, Kimberlee suggests, tends to inform most media analyses. Secondly, he draws attention to the 'politics-focussed' approach. Here, disengagement is seen 
as a consequence of the failure of outdated political institutions to reform themselves and of politicians to target young people effectively - either in their campaigning or in the substantive content of their policies. This contrasts with the third approach, which emphasises the 'alternative values' of young people, suggesting that: young people's politics is today driven by different concerns than in the past; they are motivated by lifestyle and nonmaterialist values; and that this finds expression through single issue campaigns rather than party politics. Finally, Kimberlee points to the 'generational' approach. Here, the contention is that the conditions in which young people grow up have altered dramatically over recent decades and that political disengagement is a response to wider social change which impinges on young lives - such as fewer employment opportunities, less stable families and weaker community ties.

In considering the relative merit of these different explanations, it is useful to explore policy responses to the perceived problem of youth disengagement. European Union (EU) policy over recent years has addressed, explicitly, the question of young people's political participation and the nature of their citizenship. However, to some extent this has perpetuated the view that young people are uninterested in politics (CEC 2001). The policies that have been put in place to further democratic ownership among young men and women have typically focussed on promoting active citizenship and voluntary activities (CEC 2002) but, in their emphasis on social cohesion, give relatively little recognition to the more oppositional forms of political engagement which have been documented within the academic literature (for example: Harris 2004; Nolan 2001) and which underpin Kimberlee's 'alternative value' model. While some officials have suggested that more needs to be done to engage with the types of non-formal politics favoured by the young (Hoskins 2005), this has not yet pervaded all aspects of relevant policy-making. 
In the UK, 2006 saw the publication of 'Power to the People', the report of an independent enquiry funded by the Joseph Rowntree Foundation into the alleged 'disconnect' between the public and formal politics (Power Commission 2006). In addition to exploring the reasons for this disconnection, the Commission was charged with investigating ways in which it could be reversed. Although the report does outline a significant number of recommendations, many of which are targeted specifically at young people, these are all predicated on the assumption that political apathy is largely a myth, and that the British public are not disconnected from politics generally, but only from the narrow, party-based institutional kind. Indeed, the Commission's report underlines widespread evidence of political participation across the UK, in the form of community involvement, charity work and membership of pressure groups.

While this unveiling of the 'myth of apathy' may well have been out of step with dominant political discourses in the UK and elsewhere, it offered few surprises to researchers working in this area. Indeed, over the past decade social scientists from various disciplines (notably sociology, education and politics) have called for a broader conceptualisation of the political sphere, one which recognises the importance to many citizens - but perhaps to young people in particular - of engagement in non-formal politics (Forbrig 2005; Inglehart 1990; Marsh et al. 2007). O'Toole at al. (2003), for example, have argued that understandings of politics that focus only on participation within formal arenas may not allow investigation of the many political processes that affect young people's lives such as racism or unemployment. This, they contend, is because such approaches 'assume that politics operates within arenas with reasonably porous, but stable, boundaries' and, as such, may 'overlook processes of inclusion or exclusion, which may preclude, or facilitate, entry into those arenas' (p.53). They also suggest that equating political apathy with non-participation in formal politics is simplistic 
and overlooks the possibility that, for many young people, choosing not to vote in a general election, for example, may be a conscious and politically-informed decision. Similar debates have been rehearsed in other countries, and provide important points of reference for many of the articles in this special issue. In her work with young people in Australia, for example, Vromen (2003) contends that if young people are asked about their broader political activities, including community involvement, campaigning and other forms of activism, then a considerable majority can be shown to be politically engaged.

An important strand of Vromen's argument is that politicians and others tend to downplay and even disregard forms of political engagement that do not, in their eyes, serve to maintain the status quo. Indeed, she argues that while there is call for knowledgeable, active citizenship among young people, there is a simultaneous 'othering' of alternative forms of engagement, such as anti-globalisation protests, which are not constructed as legitimate forms of participation. Studies of demonstrations by young people against the war Iraq have pointed to similar ways in which this broader type of engagement is frequently not recognised and, in some cases, even punished, by politicians, journalists and education professionals (for example: Cunningham and Lavalette 2004; Such et al. 2005). Thus, while it seems clear that young people are politically engaged in a number of different ways, problems do remain: their broader (and sometimes more oppositional) forms of political activity are often disregarded by those in power; young people have a low regard for politicians and political parties and a belief that there are few opportunities open to them to influence the political scene (Henn et al. 2005); and, to date, there are no obvious signs in many countries of the world that participation in formal politics by the under-25s is likely to increase in the near future. 


\section{The role of new media}

Developments in media and communications technologies over the last two decades have been regarded by some commentators as offering the potential for a revival of flagging democracies and of democratic participation. As societal diffusion of the internet began to take off during the 1990s, some commentators enthusiastically predicted that the interactivity and scale of 'cyberspace' would release populations from centralised, unidirectional structures of power and communication, transforming once passive audiences into empowered participants able to share knowledge, debate ideas and challenge those in power (Gilder 1994; Negroponte 1995). For some politicians, meanwhile, the potential for inclusive multi-directional discussion and knowledge sharing suggested a possible reengagement of disenchanted populations into mainstream politics and a revival of participatory democracy. Former US vice-president Al Gore was a well known proponent, endorsing the internet as 'a platform for reason', whose low entry barriers and decentralised interactivity could 'revitalize the role played by the people in our constitutional framework' (Gore 1997). In this respect, the re-engagement of young people was and remains a key focal point for such hopes, not only because participation in traditional forms of politics among youth is low, but also because they have been among the most enthusiastic adopters of internet and new media communications.

Some of this early enthusiasm about the impact of the internet on democracy, of course, has been the subject of critique, not least because similarly optimistic proclamations were made about a succession of previous communications technologies (Rhinegold 1997). Cautioning against technological determinism, critics draw attention to the speed with which new media communications, including the internet, became dominated by established interests or by equally powerful new ones (ibid.). Meanwhile, some have emphasised that, whilst the 
internet may offer individuals new opportunities to express themselves (whether politically or otherwise), such online participation may mean that individuals subject greater and greater amounts of their identities, relationships, transactions and opinions to surveillance by powerful interests (Lyon 2003). The extent to which surveillance and surveillance technologies necessarily disempower or subjugate individuals is a matter of some debate (Coleman 2007), but emphasis on such possibilities by Rheingold, Lyon and others provided a timely reminder of the complex and sometimes contradictory political implications of new technologies such as the internet.

More generally, the possibility for individuals to take advantage of new ways of participating in politics via new media has perhaps been somewhat overshadowed for young people, among other groups, by the vast range of other, more immediately enticing uses of such communicative technologies which are on offer. Through offering a seemingly unlimited choice of subject matter, activities and fellow interactants, digital media make it easier for users to completely avoid content or resources that fall outside the existing interests of themselves or their peers (Rosen 2005). As a consequence, Lievrouw asserts that internet use may 'reinforce people's identification with narrow interests, their sense of difference from other groups and indifference towards larger social concerns' (2001, p. 22). Consistent with this, recent research by Livingstone suggests that an existing sense that politics, as they understand it, is 'uncool' and 'boring' prompts the vast majority of young people to take advantage of the ability offered by a decentralised new media culture to avoid any contact with it (2007, p. 108).

For these and other reasons, the somewhat idealistic predictions of the 1990s have largely been replaced by more cautious and less deterministic approaches to the role of new media in 
relation to young people's political engagement. Nevertheless, there remains extensive interest among academics, policy makers and other practitioners both in the general implications of different forms of new communication technologies for young people's levels of political engagement and in the kinds of interventions which might be made in order to maximise any possible opportunities to garner such engagement. Such interest is reflected in large-scale funded research projects ${ }^{\mathrm{i}}$ and an increasingly extensive body of published scholarship, including two recent edited collections (Loader 2007; Dahlgren 2007). The topic also has been the subject of recent seminars and conferences, including the Young People, New Technologies and Political Engagement seminar at the University of Surrey in 2007 on which this special issue is based. ${ }^{\mathrm{ii}}$

Approaches to the role and possibilities of new media in relation to young people's engagement can be understood in relation to elements of Kimberlee's aforementioned typology of youth participation in general. Those who subscribe to the view that young people are largely uninterested and unengaged with respect to politics (as in Kimberly's 'youth focussed' approach, for example), often regard the linking of politics to new media as a potential means with which young people might be encouraged to overcome their apathy and re-engage. Amongst other things, such a view has informed an enthusiastic embrace of such technologies by politicians themselves, keen to associate themselves with and appeal to youth. Xenos and Bennett (2007) point out that the importance of online campaigning to the 2004 US primaries (notably in Howard Dean's campaign for the Democratic nomination) and subsequent presidential election coincided with increased levels of youth participation and interest in the election process. Four years later, Barack Obama's explicitly youth oriented campaign has involved extensive interactive activity on a host of social networking sites in addition to his primary campaign information site. Meanwhile in the UK, Conservative leader 
David Cameron has used a range of online tools, including online 'amateur' videos in order to appeal to young people. Self-serving though they may be, such tactics perhaps illustrate some degree of movement away from earlier political uses of the web, which were dominated by the one-way communication of information on largely static web sites (Dahlgren 2007) and towards more sophisticated interactive approaches.

Whilst examination of the role and effectiveness of these sorts of partisan tactics is of great significance, academic attention has also been focused on the development of an increasing number of non-partisan resources, explicitly oriented to the enhancement of youth participation (Xenos and Bennett 2007). Offering a mixture of information, discussion and networking facilities and a variety of other interactive resources, such youth engagement sites originate from a range of governmental and non-governmental sources. Often the development of such sites reflects not only a desire to garner young people's interest, but also an attempt, consistent with Kimberlee's 'politics focused' approach, to develop effective ways through which to convey young people's views and concerns to policy makers and more generally to enhance meaningful two-way communication between the two. Studies, including some of those in this special issue, have demonstrated the apparent value of some of these sites for those who use them but it appears to remain the case that the majority of young people are likely to have little or no contact with them (Livingstone 2007).

As well as focusing on formal political channels, youth civic sites and resources often seek to embrace and enhance youth engagement with public issues and matters of debate in a broader sense. Meanwhile, academic interest in the role of new media in relation to youth participation is sometimes focused not so much upon how to garner young people's interest in politics and more on identifying and understanding the ways in which young people are 
using ICTs as a means to express themselves politically in non-traditional ways - and even in ways which they themselves may not regard as 'politics'. Consistent with Kimberlee's 'alternative values' approach and with what Loader (2007) refers to as the 'cultural displacement' perspective, this approach emphasises the compatibilities of new media with a decentralised and often informal identity politics, often manifested in the embrace of singleissues relating to lifestyle, personal values and cultural affiliations (Webster 2001). The range of such 'non-traditional' participation via new media is potentially vast, from regularly reading the web site of an environmental pressure group, to campaigning on discussion groups to keep a local music venue open, to joining a Facebook group campaigning on eating disorders, to the ideologically motivated sharing of one's music and video files on peer-topeer sites.

\section{Outline of articles}

The collection of articles within this special issue covers the topic of young people, new technologies and political engagement from a range of perspectives and approaches. Anita Harris' focus is upon a variety of ways in which young people - and more specifically young women - are utilising online tools as a means to express themselves in what are argued to be politically active ways. Characterising the use of social networking sites and other online facilities as consistent with a form of informal DIY activism, Harris contends that ICTs are helping to offer opportunities for public expression which are absent from conventional channels of public communication. Taking a different approach, Tobias Olssen focuses upon interventions designed to utilise new media in order to enhance youth participation. Focusing on three case studies of civic web sites oriented towards young people, Olssen examines the attitudes, motivations and purposes of producers, emphasising that institutional contexts and resources have a profound impact upon the form taken by what is termed the civic web. 
Janelle Ward's article also draws upon the views of web site producers, more specifically those involved with pressure groups of various kinds in the UK. Ward's focus is upon the increasing role of consumption practices as a part of non-traditional youth politics and as a key element of the tactics of pressure groups. Ward interrogates the role of 'critical' and 'socially conscious' consumption and the nature of their relationship with more traditional forms of participation.

Phillipa Collin also focuses upon role and effectiveness of online resources in the enhancement of youth engagement, but her concern is with the experiences and viewpoints of users rather than producers. Collin explains that her respondents regarded the decentralised and flexible medium of the internet as significant in their ability and motivation to contribute to debates concerning issues that concerned them, but notes that this endorsement excluded sites of governments or others which communicated information or policy to young people in a manner perceived as one-way or patronising. Shakuntala Banaji's paper returns to broader considerations about what exactly is meant by youth civic engagement and, more specifically, what kinds of civic participation it is that governments, practitioners and academics wish to encourage. Referring to a case study in which oppositional forms of youth protest went apparently unrewarded and another in which young people had been successfully recruited to reactionary forms of politics, Banaji attempts to unpick some of the complexities, tensions and dilemmas which lie beneath the apparent rhetorical consensus that participation is, per se, a good thing.

\section{References}


Coleman, S. (2007), 'From big brother to Big Brother: Two faces of interactive engagement', in Dahlgren, P. (ed.), Young Citizens and New Media, London: Routledge, pp.21-40.

Dahlgren, P., 2007. 'Introduction: Youth, Civic Engagement and Learning via New Media, in Dahlgreh, P. (ed.), Young Citizens and New Media, London: Routledge, pp. 1-18.

Commission of the European Communities (CEC), 2001. European Commission White Paper. A New Impetus for European Youth. Brussels: The European Commission.

Commission of the European Communities (CEC), 2002. Framework of European Cooperation in the Youth Field. Brussels: The European Commission.

Cunningham, S. and Lavalette, M., 2004. ‘Active citizens' or 'irresponsible truants'? School student strikes against the war. Critical Social Policy, 24(2), 255-269.

Forbrig, J., ed. 2005. Revisiting Youth Political Participation. Council of Europe.

Gilder, G., 1994. Life After Television, New York: W. W. Norton \& Co.

Gore, A., 1997, The Assault on Reason, New York: Penguin.

Harris, A., 2004. Futuregirl. Young women in the $21^{\text {st }}$ century. London: Routledge.

Henn, M., Weinstein, M. and Forrest, S., 2005. Uninterested Youth? Young People's Attitudes Towards Party Politics in Britain. Political Studies, 53, 556-578. 
Hoskins, B., 2005. Translating research results into policy. In: J. Forbrig, J. ed. Revisiting Youth Political Participation. Council of Europe.

Inglehart, R., 1990. Culture Shift in Advanced Industrial Society. Princeton, NJ: Princeton University Press.

Kimberlee, R., 2002. Why don't British young people vote at General Elections? Journal of Youth Studies 5(1), 85-98.

Livingstone, S., 2007. Interactivity and participation on the internet: Young people's response to the civic sphere, in Dahlgren, P. (ed.), Young Citizens and New Media, London: Routledge, pp.103-124.

Lievrouw, L., 2001. 'New Media and the "Pluralization of Live-Worlds": A Role for Information in Social Differentiation', New Media and Society, 3 (1), pp. 7-28.

Loader, B., 2007. 'Introduction: Young Citizens in the Digital Age: Disaffected or Displaced?', in Loader, B. (ed.), Young Citizens in the Digital Age, London: Routledge, pp. $1-18$.

Lyon, D. (2001) Surveillance Society Buckingham: Open University Press.

Marsh, D., O’Toole, T. and Jones, S., 2007. Young People and Politics in the UK. Apathy or Alienation? Basingstoke: Palgrave. 
Negroponte, N., 1995. Being Digital. Knopf.

Nolan, M., 2001. “Opposition Machen Wir!” Youth and the contestation of civil and political legitimacy in Germany. Childhood, 8, 293-312.

O’Toole, T., Lister, M., Marsh, D., Jones, S. and McDonagh, A., 2003. Tuning out or left out? Participation and non-participation among young people. Contemporary Politics, 9(1), 45-61.

Phelps, E., 2005. Young Voters at the 2005 British General Election. The Political Quarterly, 76(4), $482-487$.

Power Commission, 2006. Power to the People. The report of Power: an independent enquiry into Britain's democracy [online]. Available from:

http://www.makeitanissue.org.uk/think_archive / [Accessed 4 June 2008].

Rhinegold, H., 1997. 'Disinformocracy' in O'Sullivan and Jewkes (eds), The Media Studies Reader, London: Arnold.

Such, E., Walker, O. and Walker, R., 2005. Anti-war children: representation of youth protests against the second Iraq war in the British national press. Childhood, 12(3), 301-326.

Vromen, A., 2003. 'People try to put us down....': participatory citizenship of 'Generation X'. Australian Journal of Political Science, 38(1), 79-99. 
Wattenberg, M., 2003. Electoral turnout: the new generation gap. British Elections and Parties Review, 13, 159-173.

Webster, F., 2001. 'A new politics?', in Webster, F. (ed.), Culture and Politics in the Information Age, London: Routledge, pp.1-14.

Xenos, M. and Bennett, L., 2007. 'Young voters and the web of politics: the promise and problems of youth-oriented political content on the web', in Loader, B. (ed.), Young Citizens in the Digital Age, London: Routledge, pp. 48-67.

\footnotetext{
${ }^{\mathrm{i}}$ Emphasis on the topic, for example, is central to the EU Framework 6 funded CIVICWEB, and also of significance to the UK Economic and Social Research Council funded 'UK Children Go Online' project and the Learn IT Research School funded 'Young Citizens, New Media and Learning'.

ii The Young People, New Technologies and Political Engagement seminar was held at the University of Surrey on 24-25 July 2007. It was funded by the University of Surrey Institute for Advanced Studies and the Social Policy Association.
} 